\title{
Telomeric Repeat-Binding Factor 1
}

National Cancer Institute

\section{Source}

National Cancer Institute. Telomeric Repeat-Binding Factor 1. NCI Thesaurus. Code C18028.

Telomeric repeat-binding factor 1 (439 aa, $\sim 50 \mathrm{kDa}$ ) is encoded by the human TERF1 gene. This protein is involved in both telomere maintenance and mitosis regulation. 